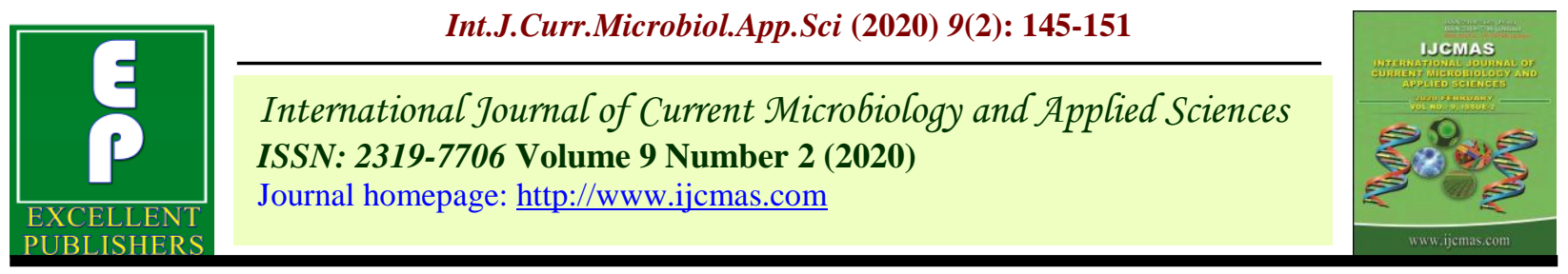

Original Research Article

https://doi.org/10.20546/ijcmas.2020.902.018

\title{
Overview of Giardia lamblia Infection based on Characteristic of HIV/AIDS Patients in West Sumatra Indonesia
}

\author{
Zahra Frizki Asty ${ }^{1 *}$, Nuzulia Irawati ${ }^{2}$ and Netti Suharti ${ }^{3}$ \\ ${ }^{1}$ Biomedical Science of Faculty of Medicine, Andalas University, Padang 25138, Indonesia \\ ${ }^{2}$ Parasitology Laboratory, Faculty of Medicine, Andalas University, Padang 25138, Indonesia \\ ${ }^{3}$ Microbiology Laboratory, Faculty of Medicine, Andalas University, Padang 25138, \\ Indonesia \\ *Corresponding author
}

\begin{abstract}
A B S T R A C T
Keywords

Giardia lamblia,

HIV/AIDS,

CD4cells, Intestinal parasite

Article Info

Accepted:

05 January 2020

Available Online:

10 February 2020

Opportunistic infections (OIs) are infections that occur due to an immune system that does not involve invasive, but can affect conditions that occur in people with a low immune system in people with HIV / AIDS. Giardia lamblia is one of the intestinal protozoa that exist in humans and animals, whereas in individuals with immunodeficiency, it can be chronic diarrhea, thus becoming dehydrated and malnourished which can increase mortality and morbidity in HIV patients. The design of this study was observational descriptive on 50 fecal samples of HIV / AIDS patients. Giardia lamblia research was carried out microscopically with Ziehl Neelsen staining. The results obtained were 1 respondents (2\%) tested positive with Giardia lamblia. From the results of this study it was concluded that HIV / AIDS sufferers in West Sumatra with a CD4 cell count of $\leq 200$ were found to be infected with Giardia lamblia
\end{abstract}

\section{Introduction}

Opportunistic infections (OIs) are infections that occur due to a decrease in the immune system. Opportunistic infections are usually not invasive, but can be fatal in people with low immune systems such as people infected with HIV / AIDS (Agarwal et al., 2015). HIV (Human Immunodeficiency Virus) is a virus that can cause acquired immunodeficiency syndrome, or known as AIDS. The HIV virus cannot be removed from the human body unlike other viruses (Sandhu et al., 2013). The target of HIV infection is CD4 T lymphocyte cells, there will be a decrease in the number and function of CD4 T cells due to the cytopathic effect of HIV infection, which leads to failure of specific and nonspecific immune functions in patients, and results in susceptibility to various infections from various microorganisms such as protozoa, bacteria, fungal and viruses 
infections (Mandal et al., 2010). Data from WHO and UNAIDS show an increase in HIV / AIDS cases in the world. In 2017 around 36.9 million cases were discovered with 1.8 million new HIV patients, and 940,000 patients died of AIDS. For the incidence of HIV / AIDS in the Asia Pacific region recorded in 2017 as many as 5.2 million cases with new HIV sufferers as many as 280,000 patients, and 170,000 patients died of AIDS (WHO, 2018; UNAIDS, 2018). Reported the number of HIV infections in Indonesia up to June 2018 was 301,959 people (47\% of the estimated number of patient with HIV / AIDS in 2018 was 640,443 people) and was most prevalent in the 25-49 years and 20-24 years age groups. Reports of cases of HIV infection by the West Sumatra Provincial Health Office in 2002-2015 recorded 1435 cases and AIDS as many as 1346 cases. In 2017 there were 418 cases of HIV and AIDS with 151 cases, and from 2002 to 2018 there were 1,890 people infected with HIV / AIDS in West Sumatra. Based on a report from the Padang City Health Office in 2018, the number of HIV / AIDS cases increased compared to 2016-2017 and 30\% of these cases were caused by Male Sex Men (MSM). (Health Ministry of Indonesia, 2018; West Sumatra Provincial Health Office. 2018)

An increase in cases of HIV / AIDS is followed by an increase in the number of cases of opportunistic infections along with the decrease in the body's defense system. One of the clinical manifestations of opportunistic infections that still cause high rates of morbidity and mortality in people with HIV / AIDS is diarrhea. Based on the Indonesian Ministry of Health's AIDS surveillance report from 1987 to June 2017, the highest case of opportunistic infections was tuberculosis by $48 \%$, followed by diarrhea by $38 \%$ and candidiasis by $14 \%$ (Health Ministry of Indonesia, 2018). One of the main agents causing diarrhea HIV / AIDS patients are intestinal parasites (Heru, 2010).
Intestinal protozoa that often cause disease in HIV patients include Entamoeba histolytica, Cryptosporidium sp. and Giardia lamblia (Deb et al., 2015).

Giardia lamblia are protozoa that have flagella, in two forms, namely trophozoites and cysts. The form of infection and environmental resistance is a cyst (Erickson, 2006). These protozoa can be transmitted directly via the fecal-oral route or indirectly through consumption of contaminated water or food (Yoder et al., 2008; Agarwal et al., 2010). Some groups of people have a greater risk of being infected with Giardia, among others: people who suffer from immune system disorders, being in an area that lacks clean water supply for drinking, swim in rivers, lakes or ponds where parasites live, and have pets that can make contact with animals that are infected by parasites (Khomdonet al., 2009)

Based on risk factor of being infected with Giardia, this study was conducted which aims to look overview Giardia lamblia infections based on characteristic of HIV/AIDS patients.

\section{Materials and Methods}

\section{Collection of samples}

Fecal samples was collected from HIV/AIDS patients at Dr. M. Djamil Padang Hospital Indonesia. Characteristic patients and secondary data was collected from the medical record and questionnaires such as age, CD4 cell count, HIV risk factors, take ARV therapy /no, pet, drinking water.

\section{Giardia examination}

Examination was carried out with ZiehlNeelsen staining. Take the fecal with size of green bean seeds with a small stick or cotton swab and blotted on the glass object, let it dry at room temperature. Then fixation 
on the flame of spiritus. Fixation with methanol for 5 minutes. Dry at room temperature. Preparations placed on the coloring rack. Concentrated carbol fuchsin is dripped until it floods the entire surface of the preparation for 15 minutes then wash with running water. Drop the alcoholic acid solution (HCl-methanol) for the decolorization process until there is no more carbol fuchsin coloring for 3 minutes, then rinse again using running water. Drop the malachite solution over the entire surface of the preparation for 30 seconds until 1 minute. Wash the preparation again with running water. Dry it on its side in the open air. give one drop then cover with glass cover, let stand for a while until the glass cover closes well. Observe the cyst under a microscope at 1000x magnification. The cyst will look pink to red with a size of $4-6 \mu \mathrm{m}$.

\section{Results and Discussion}

In this study, data was obtained from the VCT Poly RSUP Dr. M. Djamil Padang as many as 50 respondents, it was found that most were male with 37 respondents $(74 \%)$, with the most age categories in the range of 26-35 years as many as 23 respondents (46\%). All patients were receiving ARV therapy (100\%), with CD4 cell count $\leq 200$ cell / $\mu \mathrm{L}$ of 25 respondents $(50 \%)$ and $>200$ cells / $\mu \mathrm{L}$ of 25 respondents(50\%), 37 respondents $(74 \%)$ contact with pets, and 33 respondents $(66 \%)$ drink with boiled water.

The most characteristic are male as many as 37 people $(74 \%)$ with the age category in the range of 26-35 years as many as 23 people (46\%). In line with the study of Pavie et al., (2012) which stated that the most HIV / AIDS sufferers were male (76\%) with an age category <40 years, and Akinbo et al., (2010) also stated that in his study the most HIV sufferers were male (18.6\%). All patients were receiving ARV therapy (100\%). This is in accordance with WHO which states that adults who have a CD4 cell count of $\leq 350$ cells / $\mu \mathrm{L}$ are the top priority in the administration of ARV, where ARV therapy can control viral replication and increase CD4 cell counts, thereby extending the asymptomatic phase of infection, slowing the progression of the disease and help reduce the risk of transmission, and infections of other serious opportunistic diseases that can be cured, although these drugs only play a role in inhibiting viral replication but cannot eliminate viruses that have developed (Bhatti, et al., 2016; Djauzi dan Djoerban, 2009).

More than half of respondents (74\%) kept dogs, cats, chicken, cow, and goat as their pets. Most of these pets are left to roam freely. The respondents have very close contact with the pets. Contact with pets is a risk factor that can cause Giardia lamblia infection. One of the risk factors for Giardia lamblia infection is water, which This protozoan life cycle begins with ingestion of cysts that are abundant in environment such as water, both engulfed by animals and humans. 33 respondents $(66 \%)$ were obtained using bottled water as a source of drinking water.

Sufferers HIV / AIDS should maintain the cleanliness of the water used or consumed. Some recommended ways are boiling, filtering, flocculation, and disinfection using sunlight or ultraviolet which is able to eliminate or deactivate pathogenic microbes. Bottled water is usually not boiled, only using a micro filter. While boiling water can kills a lot of bacteria, however, it doesn't remove dissolved chemicals or particulates (Bouzid et al., 2018).

The most characteristic are male as many as 37 people $(74 \%)$ with the age category in the range of 26-35 years as many as 23 people (46\%). In line with the study of Pavie et al., (2012) which stated that the most HIV / AIDS sufferers were male $(76 \%)$ with an age 
category <40 years, and Akinboet al., (2010) also stated that in his study the most HIV sufferers were male $(18.6 \%)$.

All patients were receiving ARV therapy $(100 \%)$. This is in accordance with WHO which states that adults who have a CD4 cell count of $\leq 350$ cells / $\mu \mathrm{L}$ are the top priority in the administration of ARV, where ARV therapy can control viral replication and increase CD4 cell counts, thereby extending the asymptomatic phase of infection, slowing the progression of the disease and help reduce the risk of transmission, and infections of other serious opportunistic diseases that can be cured, although these drugs only play a role in inhibiting viral replication but cannot eliminate viruses that have developed (Bhatti, et al., 2016; Djauzi dan Djoerban, 2009).

More than half of respondents (74\%) kept dogs, cats, chicken, cow, and goat as their pets. Most of these pets are left to roam freely. The respondents have very close contact with the pets. Contact with pets is a risk factor that can cause Giardia lamblia infection. One of the risk factors for Giardia lamblia infection is water, which this protozoan life cycle begins with ingestion of cysts that are abundant in environment such as water, both engulfed by animals and humans. 33 respondents $(66 \%)$ were obtained using bottled water as a source of drinking water.

Table.1 Characteristic of respondents

\begin{tabular}{|c|c|c|}
\hline Characteristic & Frequency & $\%$ \\
\hline \multicolumn{3}{|l|}{ - Gender } \\
\hline Male & 37 & 74 \\
\hline Female & 13 & 26 \\
\hline \multicolumn{3}{|l|}{ - Age } \\
\hline 0-16 years old & 1 & 2 \\
\hline 17-25 years old & 9 & 18 \\
\hline 26-35 years old & 23 & 46 \\
\hline $36-45$ years old & 14 & 28 \\
\hline 46-55 years old & 3 & 6 \\
\hline \multicolumn{3}{|l|}{ - CD4 cell count } \\
\hline$\leq 200 \mathrm{cell} / \mu \mathrm{L}$ & 25 & 50 \\
\hline$>200$ celll $/ \mu \mathrm{L}$ & 25 & 50 \\
\hline \multicolumn{3}{|l|}{ - ARV } \\
\hline ARV & 50 & 100 \\
\hline \multirow{5}{*}{$\begin{array}{ll} & \text { Non ARV } \\
\text { - Contact with Pet } \\
\text { Yes } \\
\text { No } \\
\text { - Drinking water } \\
\text { Bottled water } \\
\text { Boiled water }\end{array}$} & 0 & 0 \\
\hline & 37 & 74 \\
\hline & 13 & 26 \\
\hline & 33 & 66 \\
\hline & 17 & 34 \\
\hline
\end{tabular}


Table.2 Giardia lamblia infection based on CD4 cell count

\begin{tabular}{|c|c|c|c|}
\hline Patient Criteria & \multicolumn{2}{|c|}{ Results } & Total (\%) \\
\hline & Positive (\%) & Negative (\%) & $\mathrm{n}=50$ \\
\hline $\mathbf{C D 4} \leq \mathbf{2 0 0}$ cell/ $/ \mathbf{\mu L}$ & $1(2 \%)$ & $24(48 \%)$ & $25(50 \%)$ \\
\hline $\mathbf{C D 4} \mathbf{> 2 0 0}$ cell/ $\mathbf{\mu L}$ & $0(0 \%)$ & $25(50 \%)$ & $25(50 \%)$ \\
\hline Total & $1(2 \%)$ & $49(98 \%)$ & $50(100 \%)$ \\
\hline
\end{tabular}

Fig.1 The results of the examination of Giardia lamblia

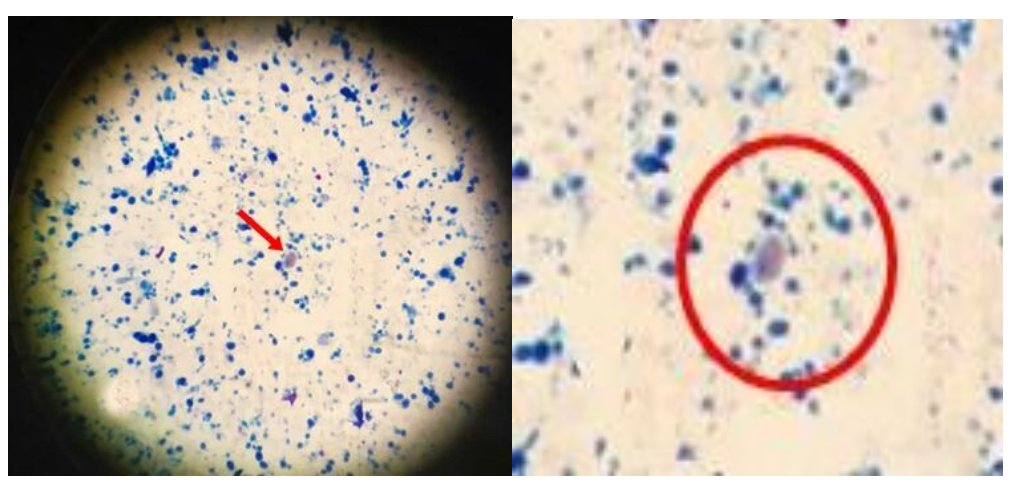

Sufferers HIV / AIDS should maintain the cleanliness of the water used or consumed. Some recommended ways are boiling, filtering, flocculation, and disinfection using sunlight or ultraviolet which is able to eliminate or deactivate pathogenic microbes. Bottled water is usually not boiled, only using a micro filter. While boiling water can kills a lot of bacteria, however, it doesn't remove dissolved chemicals or particulates (Bouzid et al., 2018).

In this study the results of the examination of Giardia lamblia using Ziehl-Neelsen, a positive total of 1 respondents (2\%) was obtained with a CD4 cell count of $\leq 200$ cells $/ \mu \mathrm{L}$. A low CD4 cell count indicates a decrease in the immune system, and can cause various microorganisms such as bacteria, viruses, fungi, and protozoa to tend to grow and multiply causing secondary infections, especially in individuals with HIV infection at risk of infection with Giardia lamblia if CD4 $\leq 400$ cell $/ \mu \mathrm{L}$ (Faria et al., 2017).
In this study the results of Giardia lamblia examination obtained a positive total of 1 respondents (2\%) with a CD4 cell count of $\leq 200$ cells / $\mu \mathrm{L}$. The discovery of Giardia lamblia in the form of cysts is based on the morphological characteristics of Giardia lamblia, which is an oval shaped cyst that has a length of about 8-12 microns, has thin and strong walls. The cytoplasm is fine-grained and is clearly separated from the cyst wall. Then the cyst found clearly has 2 nuclei which indicate that it is in an immature cyst stage. In line with the research of Ekhlas et al., (2012), cyst of Giardia lamblia oval in shape, and measures 8 to $12 \mu \mathrm{m}$ in length. The cytoplasm is retracted from the cyst wall and has 4 nuclei at 1 pole, where the cyst has 4 nuclei which indicate that it is in a mature cyst stage. Then in the study of Nasimuddin $e t$ al., (2014), from the results of his research it was also found that Giardia lamblia cysts were oval in shape and about $10 \mu \mathrm{m}$ in size with axostyle and prominent nuclei were observed, there were cysts that had 2 nuclei and some had 4 nuclei. 


\section{References}

Agarwal, S.G., Powar, R.M., Tankhiwale, S., Rukadikar, A. Study of opportunistic infections in HIV-AIDS patients and their co-relation with CD4+ cell count. Int J Curr Microbiol App Sci. 2015; 4(6):848-61.

Akinbo FO, Okaka, Omorogie R. Prevalence of intestinal parasitic infections among HIV patients in Benin City, Nigeria. Libyan Journal of Medicine. 2010; 5(1).

Bhatti,AB, Usman, M, Kandi, V. Current Scenario of HIV/AIDS, Treatment Options, and Major Challenges with Compliance to Antiretroviral Therapy. Cureus Publishing. 2016;8(3): 515

Bouzid M, Kintz E, Paul RH. Risk factors for Cryptosporidium infection in low and middle income countries: A systematic review and meta-analysis. PLoS Neglected Tropical Diseases. 2018;12(6).

Deb M, Joseph A, Khalil S, Mirdha BR, Panda A, Sinha SSY. 2015. Intestinal parasitosis in relation to ART, CD4 Tcell count and diarrhea in HIV patients. Korean J Parasitol. 2015;53(6): 705-712

Djauzi, Djoerban Z. 2009. HIV / AIDS in Indonesia - Internal Medicine Volume III Edition V. Jakarta: Department of Internal Medicine FKUI

Ekhlas AH, Azza KA, Basma AA, Fadia AM. Opportunistic Parasites among Immunosuppressed Children in Minia District, Egypt. Korean Journal of Parasitology. 2012; 50(1): 57-62.

Erickson MC, Ortega YR. Inactivation of protozoan parasites in food, water, and environmental systems. $J$ Food Prot. 2006;69(11):2786-2808.

Faria CP, Zanini GM, Dias G2, Sousa MDC. Associations of Giardia lamblia assemblages with HIV infections and symptomatology: HIV virus and assemblage $\mathrm{B}$ were they born to each other. Journal of Medicine Institutes of Health. 2017; 11(8).

Health Ministry of Indonesia. 2018. Indonesia Health Profile 2018. Jakarta:

Heru, P. 2010. Intestinal Parasites Infection in AIDS Patients with Chronic Diarrhea at Dr. Soetomo General Hospital Surabaya. Indonesian Journal of Tropical and Infectious Disease. 2010:1(1).

Khomdon S.L, Sucitra L. 2009. Nutrition and AIDS. Delhi: Singhal Print Media

Mandal K, Edmund G, Edward G, Richard T. 2010. Penyakit Infeksi . Edisi ke enam . Jakarta : Erlangga 199-203.

Nasimuddin S, Malayan J, Gnanadesikan S, Kandaswamy M. A Case Report of Strongyloidiasis Associated with Giardiasis in a Patient With Renal Calculi From a Tertiary Care Center in South India. Journal of Global Infectious Diseases. 2014; 6(3): 137.

Pavie J, Menotti J, Porcher R, Donay JL, Gallien S, Sarfati C, Derouin F, Molina JM. Prevalence of Opportunistic Intestinal Parasitic Infections among HIV-Infected Patients with Low CD4 cells counts in France in The Combination Antiretroviral Therapy Era. International Journal of Infectious Disease. 2012; 16(9): 677-679

Sandhu, A, Samra, A.K. Opportunistic Infections and Disease Implications in HIV/AIDS. International Journal of Pharmaceutical Science Invention. 2013; 2(5): 47-54.

UNAIDS. 2018. United Nations Programme on HIV and AIDS

West Sumatra Provincial Health Office. 2018. West Sumatra HIV / AIDS profile

WHO. 2018. National AIDS control programme: WHO

Yoder JS, Harral C, Beach MJ, Centers for Disease C, Prevention. Giardiasis surveillance - United States, 2006-2008. MMWR SurveillSumm. 2010; 59(6):15-25. 


\section{How to cite this article:}

Zahra Frizki Asty, Nuzulia Irawati and Netti Suharti. 2020. Overview of Giardia lamblia Infection based on Characteristic of HIV/AIDS Patients in West Sumatra Indonesia. Int.J.Curr.Microbiol.App.Sci. 9(02): 145-151. doi: https://doi.org/10.20546/ijcmas.2020.902.018 